\title{
Mobile Forms of Gold and Pathfinder Elements in Surface Sediments at the Novye Peski Gold Deposit and in the Piilola Prospecting Area (Karelia Region)
}

\author{
Vera Alexandrovna Korshunova * and Marina Valentinovna Charykova \\ Institute of Earth Sciences, Geochemistry Department, St.-Petersburg State University, \\ 7-9 University Embankment, 199034 Saint-Petersburg, Russia; m.charykova@spbu.ru \\ * Correspondence: vera@kareliangold.com; Tel.: +7-950-021-0353
}

Received: 9 December 2018; Accepted: 4 January 2019; Published: 11 January 2019

\begin{abstract}
The success of prospecting for gold deposit in overburdened areas based on the using of secondary dispersion haloes mostly depends on the chosen method of geochemical survey (sampling horizon, sample preparation for analysis, etc.). At the same time, the geochemistry of gold in the supergene zone is insufficiently studied, especially it's migration and concentration in association with other elements in surface sediments due to weathering of gold-bearing ore. The main aim of the study presented in this paper is the determination of mobile forms of gold and pathfinder elements (As, $\mathrm{Cu}, \mathrm{Ni}, \mathrm{Ag}, \mathrm{Zn}, \mathrm{Pb}, \mathrm{Se}, \mathrm{Sb}, \mathrm{Mo}, \mathrm{Bi}$, and $\mathrm{Te}$ ) in podzol soil and moraine in the areas of Karelia region with known gold mineralization. As a result of conducted experiments it was determined that the main mobile forms of gold are water-soluble and bound to organic matter, while pathfinder elements bound preferably to Fe and Mn(hydr)oxides and to organic matter. As gold and some pathfinders bind with organic matter, this form was considered in more detail, and the elements' interaction with humic and fulvic acids was investigated. In addition, it was determined that the studied elements are quite "mobile" because the percentage of the mobile form in their total content was mostly more than $50 \%$. The main features of the elements' migration and concentration were identified in surface sediments of the study areas.
\end{abstract}

Keywords: gold; pathfinders; mobile forms; humic and fulvic acids; podzols; moraine

\section{Introduction}

Currently, prospecting for gold deposits is mostly being carried out in overburden-affected areas. The degree of overburden can vary at first to dozens of meters, which makes prospecting more difficult to carry out, because gold is characterized by a low abundance in upper crust (1.5 $\mathrm{ng} \cdot \mathrm{g}^{-1}$ [1]) and especially in overburdened areas. In consequence of the high cost of low-concentration analysis, prospecting is often based on the use of elements associated with gold mineralization in primary haloes, such as $\mathrm{Te}, \mathrm{Bi}, \mathrm{As}, \mathrm{Ag}, \mathrm{Cu}, \mathrm{Sb}$, etc. [2-6]. However, these elements, forming anomalies in a secondary halo while weathering gold-bearing ore, no longer have a close positive correlation compared to it in the primary halo and sometimes this correlation is lost completely in a large-scale geochemical survey. That is why selecting elements as indicators of gold mineralization should be based not only on genetic relations between the elements in the primary halo, but also on their migration features in the secondary halo. Another aspect of solving the problems of prospecting for gold deposits is the use of geochemical methods based on the analysis of an element's mobile form (CHIM-partial leaching of metals; TMGM - thermomagnetic geochemical method; MMI-mobile metal ion extraction; MOMEO-leaching of mobile forms of metals in overburden; enzyme leaching, etc.), because the full amount of the element corresponds to the sum of several processes, which are thus averaged 
and do not always show contrast anomalies, compared to the anomalies identified with mobile form analysis [7]. However, using geochemical methods based on mobile forms analysis requires knowledge of gold migration and concentration features in the supergene zone, and the information about this remains incomplete as of today, despite a significant amount of research being conducted in this field [8-11]. Therefore, the purpose of this study was to identify the main mobile forms of gold and its pathfinders and to compare the futures of their concentration in different horizons of loose sediments in the areas with known primary gold mineralization for the understanding of what mobile form of gold and associated elements could point onto overlaying ore body.

\section{Materials and Methods}

\subsection{Geology of Study Areas}

The study of gold and pathfinder's mobile forms in loose sediments was carried out in two territories at Karelia region-the territory of Novye Peski gold deposit and Piilola prospecting area. Novye Peski gold deposit is located within the Segozero-Vedlozero Archean greenstone belt. Piilola prospecting area is located within the Kuhmo Archean greenstone belt, where there are known gold ore occurrences (Piilola, Josijarvi, Muesuo, etc.) (Figure 1).

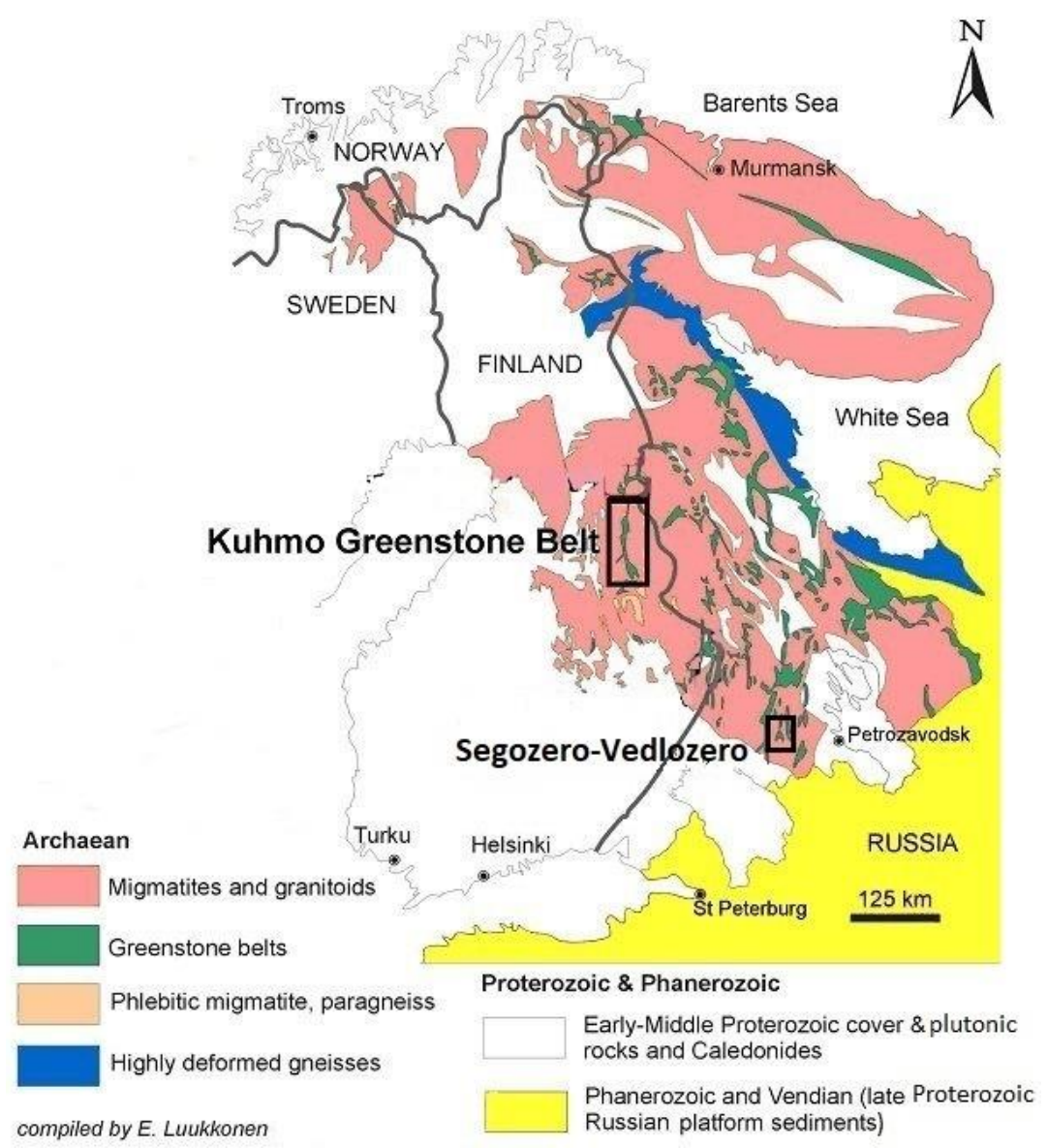

Figure 1. The geological structure of Karelia and location of the studied areas [12].

Mobile forms of gold and pathfinders were studied in loose sediments near the Josijarvi gold ore occurrence in the Piilola area. It is hosted by intermediate metatuff. Zones with an elevated gold concentration are confined to micaceous schists and are characterized by increased arsenic content. Ore mineral associations are represented by arsenopyrite and pyrrhotite with occasional aggregates of chalcopyrite, sphalerite, pentlandite, pyrite; silver and copper are presented as impurities. The native 
gold and bismuth intergrowths are also characteristic [12,13]. The supposed exploration model is the intrusion related gold system combined with the hosted orogenic shear zone [14].

The main types of host rocks of the Novye Peski deposit are metamorphosed basalts, andesibasalts and their tuffs, amphibolites over gabbro or gabbro-amphibolites, including garnet and epidote with magnetite and ilmenite. The veinlet-impregnated vein of gold-sulfoarsenide ore mineral association includes arsenopyrite, lellingite, pyrite, pyrrhotite, chalcopyrite, sphalerite, glaucodotite, galena, scheelite, gold, and occasional aggregates of bismuth and maldonite. Ore mineralization is confined to the schistosity zone with a N-E orientation (shear zone) in metamorphosed and altered gabbroids [15]. According to the latest investigations, the Novye Peski gold deposit can be categorized as the orogenic genetic type $[15,16]$. There are granitoids with a suggested age of $2.7 \mathrm{Ga}$, but the relation of gold mineralization to intrusion is not obvious [16]. Novye Peski is a small deposit with $\mathrm{P}_{1}$ reserves of 5.8 tons of gold [15].

\subsection{Sampling, Mineralogical, and Chemical Characteristic of Surface Sediment Horizons}

The territory of the study areas is covered by loose sediments, represented by moraine and podzols developing on it $[17,18]$. The territory of sampling at Novye Peski is characterized by the distribution of thin, weathered moraine, which does not differ in its features from the soil-forming horizon C, compared to moraine in the Piilola area, where the weathering processes are slower, and the moraine keeps its texture and structure. Rustic Podzols (FAO 1998) are developed in the Novye Peski area, according to the national soil atlas of Russian Federation, and Haplic Podzols are the most common in Finland according to data from the Soil Geographical Database of Europe presented by Yli-Hala [19]. The type of considered soil has the following profile: $\mathrm{O}-\mathrm{AO}-\mathrm{E}-\mathrm{Bf}(\mathrm{Bhf})-\mathrm{C}$.

Loose sediment samples were collected from three vertical sections at each study area: over the mineralized zone (profile No. 1), near (profile No. 2) and away from it (profile No. 3) in the territory of the Novye Peski deposit, and within the area with gold and arsenic anomalies in the secondary dispersion halo in the Piilola area (profiles No. 1, No. 4 and No. 10) (Figure 2). Thus, 9 samples from Novye Peski area and 12 samples from the Piilola prospecting area were collected to identify mobile forms of elements. The main chemical and mineralogical characteristics of samples are shown in Tables 1 and 2. Organic carbon was determined with $\mathrm{CHN}$ analysis. Soil $\mathrm{pH}$ was measured in water extract [20]. Mineral phases were identified with X-ray powder diffraction and clay mineral content with full-profile Ritveld quantitative XRD analysis (Supplementary Figures S1-S4).

Table 1. The main chemical and mineralogical overburden and bedrock properties at Novye Peski.

\begin{tabular}{ccccc}
\hline $\begin{array}{c}\text { Horizon } \\
\text { (Depth, cm) }\end{array}$ & pH & $\begin{array}{c}\text { Organic } \\
\text { Carbon, } \%\end{array}$ & $\begin{array}{c}\text { Clay } \\
\text { Minerals, } \%\end{array}$ & Mineral Phases \\
\hline $\begin{array}{c}\text { E } \\
(20-30)\end{array}$ & $4.9-5.4$ & $0.45-0.66$ & 4 & $\begin{array}{l}\text { quartz, microcline, albite, hornblende, } \\
\text { muscovite, calcite, dolomite }\end{array}$ \\
\hline $\begin{array}{c}\text { Bf } \\
(40-50)\end{array}$ & $5.7-6.0$ & $1.00-1.44$ & 7 & $\begin{array}{l}\text { quartz, albite, microcline, hornblende, } \\
\text { biotite, chlorite }\end{array}$ \\
\hline $\begin{array}{c}\text { C } \\
(10 \mathrm{~cm} \text { over } \\
\text { bedrock })\end{array}$ & $5.2-6.4$ & $0.09-0.54$ & 12 & $\begin{array}{l}\text { quartz, albite, hornblende, muscovite, } \\
\text { microcline, talc, chlorite }\end{array}$ \\
\hline $\begin{array}{c}\text { Bedrock } \\
(\text { first } 10 \mathrm{~cm})\end{array}$ & - & $\begin{array}{l}\text { Type of rock: amphibolite } \\
\text { Minerals: amphibole, chlorite, quartz, } \\
\text { plagioclase, biotite, epidote, } \\
\text { tourmaline, garnet; ilmenite, titanite, } \\
\text { pyrrhotite, chalcopyrite, pyrite, } \\
\text { arsenopyrite, magnetite [21] }\end{array}$ \\
\hline
\end{tabular}

${ }^{1}$ Data of gold concentration in profile No. 1 determined with LA ICP-MS in surface sediments and with ICP-MS method in rock according to procedure of NSAM No. 499. 
Table 2. The main chemical and mineralogical overburden and bedrock properties in the Piilola prospecting area.

\begin{tabular}{|c|c|c|c|c|c|}
\hline $\begin{array}{c}\text { Horizon } \\
(\text { Depth, cm) }\end{array}$ & $\mathrm{pH}$ & $\begin{array}{c}\text { Organic } \\
\text { Carbon, } \%\end{array}$ & $\begin{array}{c}\text { Clay } \\
\text { Minerals, \% }\end{array}$ & Mineral Phases & $\mathrm{Au}{ }^{1}, \mathrm{ppm}$ \\
\hline $\begin{array}{c}\mathrm{E} \\
(10-12)\end{array}$ & $5.6-6.9$ & $0.55-1.05$ & 5.8 & $\begin{array}{l}\text { quartz, plagioclase, amphibole, } \\
\text { montmorillonite, talc }\end{array}$ & 0.0026 \\
\hline $\begin{array}{l}\text { Bhf } \\
(30-40)\end{array}$ & $5.1-5.6$ & $1.08-3.34$ & 9.2 & $\begin{array}{l}\text { quartz, plagioclase, muscovite, } \\
\text { hydromuscovite, chlorite, } \\
\text { amphibole, kaolinite }\end{array}$ & 0.0029 \\
\hline $\begin{array}{c}\text { C } \\
(80-100)\end{array}$ & $5.2-5.7$ & $0.14-0.77$ & 7.5 & $\begin{array}{l}\text { quartz, plagioclase, microcline, } \\
\text { muscovite, chlorite, amphibole, } \\
\text { pyrophyllite, dolomite, sepiolite }\end{array}$ & 0.0025 \\
\hline $\begin{array}{c}\text { moraine } \\
(150-300)\end{array}$ & $5.5-7.0$ & $0.14-3.30$ & $13.1-16.6$ & $\begin{array}{l}\text { quartz, microcline, chlorite, albite, } \\
\text { amphibole, muscovite, talc, kaolinite }\end{array}$ & 0.0020 \\
\hline $\begin{array}{l}\text { Bedrock } \\
\text { (first } 10 \mathrm{~cm} \text { ) }\end{array}$ & - & - & - & $\begin{array}{l}\text { Type of rock: granite } \\
\text { Minerals: feldspar, quartz, muscovite, } \\
\text { chlorite, biotite, calcite, zoisite } \\
\text { Type of rock: amphibolite } \\
\text { Minerals: amphibole, biotite, chlorite }\end{array}$ & 0.0231 \\
\hline
\end{tabular}

${ }^{1}$ Data of gold concentration in profile No. 1 determined with LA ICP-MS in surface sediments and with ICP-MS method in rock according to procedure of NSAM No. 499.

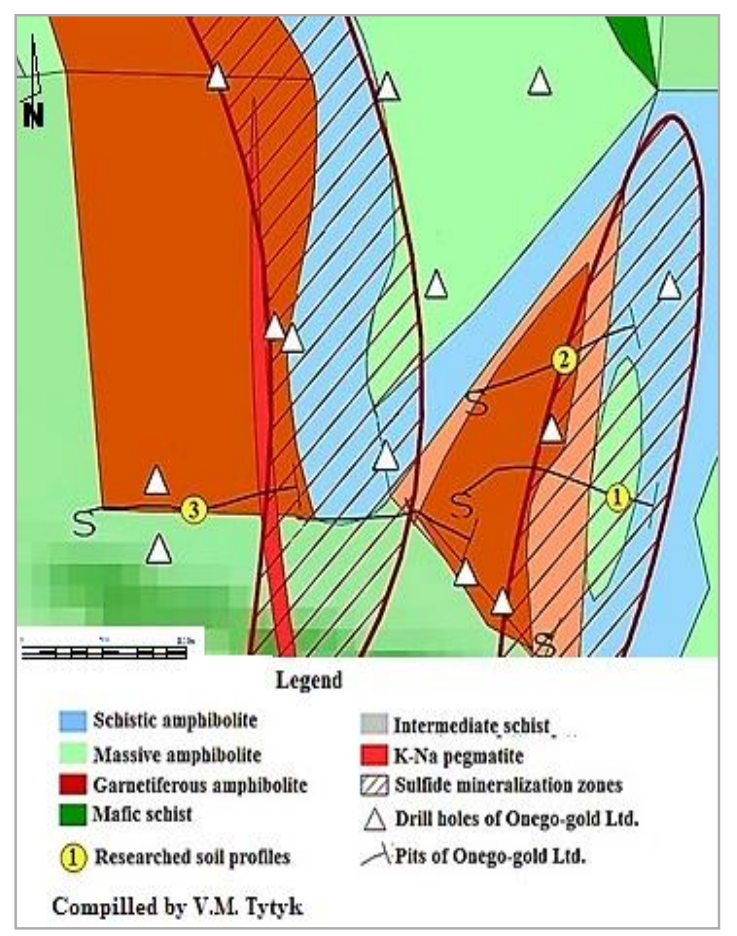

(a)

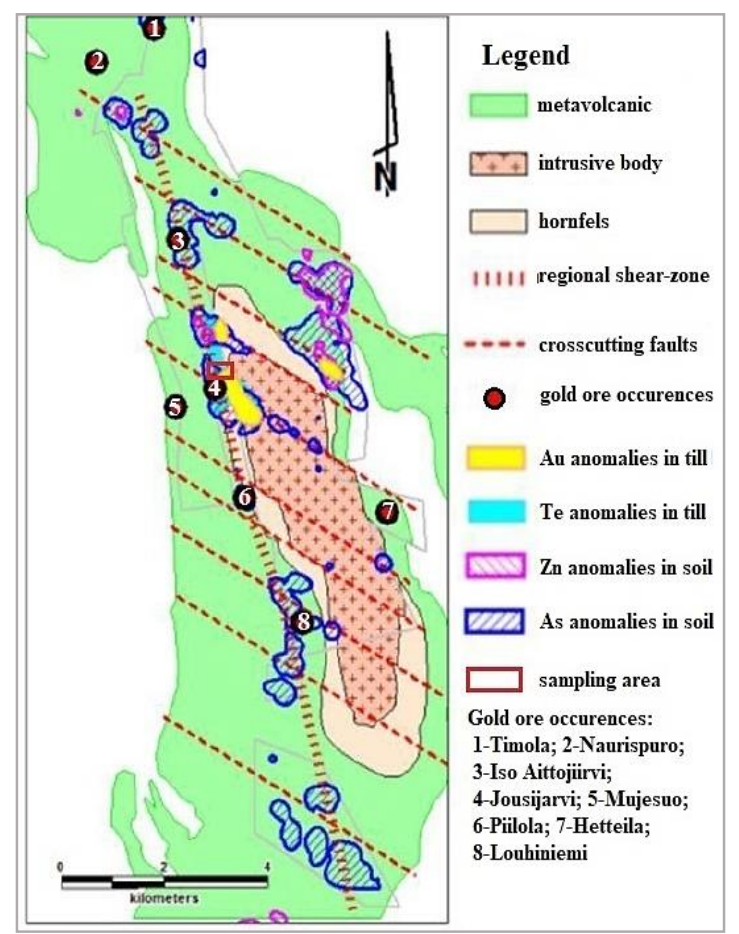

(b)

Figure 2. Places of sampling in the Novye Peski (a) and Piilola (b) [14] areas.

\subsection{Methods of Determining Gold and Pathfinder Mobile Forms}

The selection of elements as pathfinders for mobile form determination was based on data regarding ore mineral associations in gold ore occurrences located within study areas [14,15], and on the data about the elements most often associated with gold in the Baltic Shield [22,23]. Thus, mobile forms of gold and pathfinders, such as $\mathrm{As}, \mathrm{Ag}, \mathrm{Cu}, \mathrm{Ni}, \mathrm{Zn}, \mathrm{Pb}, \mathrm{Te}, \mathrm{Se}, \mathrm{Mo}, \mathrm{Bi}$, and $\mathrm{Sb}$, were identified in this study. 
Determinations of gold and pathfinder mobile forms were conducted with the sequential extraction method $[24,25]$ with a further ICP-MS analysis of the extracts. The sequential extraction is usually used for determination of forms of elements, but also it experimentally models the interaction of elements with natural water: the low water mineralization can cause the water-soluble form leaching, the increasing of water mineralization-leaching of forms of elements related to ions exchange. $\mathrm{pH}$ changes can contribute onto dissolution or precipitation of carbonate forms and forms bound to organic matter. Forms bound to Fe and Mn (hydr)oxides are the less mobile and can dissolve due to the destruction of adsorbent. We used the sequential extraction procedure consisting of six steps (as shown in Table 3); the seventh step is the insoluble residue digestion of loose sediment samples, which was done to evaluate the parts of the mobile and residual forms.

Table 3. Sequential extraction procedure.

\begin{tabular}{ccc}
\hline Step & Target Phase & Extractant \\
\hline 1 & Water-soluble & $\mathrm{H}_{2} \mathrm{O}+\mathrm{C}_{2} \mathrm{H}_{5} \mathrm{OH}$ \\
2 & Loosely adsorbed (cations exchange) & $1 \mathrm{~N} \mathrm{BaCl}_{2}$ \\
3 & Strongly adsorbed (anions exchange) & $1 \mathrm{~N} \mathrm{NaH}_{2} \mathrm{PO}_{4}$ \\
4 & Bound to organic matter & $0.1 \mathrm{M} \mathrm{Na} \mathrm{P}_{2} \mathrm{O}_{7} \cdot 10 \mathrm{H}_{2} \mathrm{O}$ \\
5 & Bound to carbonates & $1 \mathrm{~N} \mathrm{CH}_{3} \mathrm{COONa}+1 \mathrm{~N} \mathrm{CH}_{3} \mathrm{COOH}, \mathrm{pH}=5.5$ \\
6 & Bound to iron and manganese (hydr-)oxides & $6 \mathrm{~N} \mathrm{HCl}^{-} \mathrm{HCO}$ \\
7 & Insoluble residue & $\mathrm{HF}$ and H $\mathrm{SO}_{4}$ \\
\hline
\end{tabular}

The extraction of humic (HA) and fulvic (FA) acids was conducted according to the pyrophosphate express method of Kononova and Belchikova with modifications by V.V. Ponamoreva and T.A. Plotnikova [26], with the further multi-element analysis of extracts with the ICP-MS method. The full quantity of HA and FA carbon were determined with the I.V Turin method with V.N. Simakov's modification [27].

\section{Results}

\subsection{Analysis of Mobile Forms of Gold and Pathfinder Elements}

The results of the conducted experiment show that the main mobile forms of gold are water-soluble and bound to organic matter in loose sediments in the Piilola area and at Novye Peski, and gold is also bound to Fe and Mn (hydr-)oxides at Novye Peski, but in a lower grade (Tables 4 and 5, Supplementary Table S1). In contrast to gold, none of the pathfinders have a high percentage of their water-soluble form, and those elements bound preferably to Fe and Mn (hydr-)oxides, except for tellurium, mobile forms of which are strongly adsorbed and bound to organic matter in both areas and bound to $\mathrm{Fe}$ and $\mathrm{Mn}$ (hydr-)oxides in the Piilola area. $\mathrm{Cu}, \mathrm{Ni}, \mathrm{Ag}, \mathrm{Bi}$, and $\mathrm{Pb}$ are mainly bound to $\mathrm{Fe}$ and $\mathrm{Mn}$ (hydr-)oxides in both study areas. For arsenic and selenium, this form also plays an important role; however, those elements are in a strongly adsorbed form in loose sediments in the Piilola area, which is changed on being bound to organic matter at Novye Peski. Molybdenum and antimony also have some differences in loose sediments: they are bound preferably to organic matter and Fe and $\mathrm{Mn}$ (hydr-)oxides in the Piilola area and bound only to Fe and Mn (hydr-)oxides in the Novye Peski area. Thus, based on the obtained data, we can point to the groups of elements with similar types of mobile forms in both areas: $\mathrm{Au}, \mathrm{Cu}, \mathrm{Ni}, \mathrm{Ag}, \mathrm{Bi}, \mathrm{Pb}$, and with some changes, $\mathrm{As}$, Se, $\mathrm{Mo}$, and $\mathrm{Sb}$. 
Table 4. Mobile forms of gold and pathfinder elements in surface sediments at Novye Peski.

\begin{tabular}{|c|c|c|c|c|c|c|}
\hline $\begin{array}{c}\text { Form } \\
\text { Percentage }\end{array}$ & Water-Soluble & $\begin{array}{l}\text { Loosely } \\
\text { Adsorbed }\end{array}$ & $\begin{array}{l}\text { Strongly } \\
\text { Adsorbed }\end{array}$ & $\begin{array}{l}\text { Bound to } \\
\text { Organic } \\
\text { Matter }\end{array}$ & $\begin{array}{l}\text { Bound to } \\
\text { Carbonates }\end{array}$ & $\begin{array}{c}\text { Bound to Fe } \\
\text { and Mn (Hydr-) } \\
\text { Oxides }\end{array}$ \\
\hline$>50$ & & & & & & $\begin{array}{l}\mathrm{Cu}, \mathrm{Ni}, \mathrm{Ag}, \mathrm{Sb} \\
\mathrm{Mo}, \mathrm{Bi}, \mathrm{Zn}, \mathrm{Pb}\end{array}$ \\
\hline $30-50$ & $\mathrm{Au}$ & & $\mathrm{Te}$ & $\begin{array}{l}\mathrm{Au}, \mathrm{As}, \mathrm{Ag}, \\
\quad \mathrm{Se}, \mathrm{Te}\end{array}$ & & As, Se \\
\hline $15-30$ & & & & $\begin{array}{l}\mathrm{Cu}, \mathrm{Sb}, \mathrm{Bi} \\
\mathrm{Pb}\end{array}$ & & $\mathrm{Au}$ \\
\hline 5-15 & Se, Mo & $\mathrm{Au}, \mathrm{Cu}, \mathrm{Zn}$ & As, Ni, Ag & $\mathrm{Ni}, \mathrm{Mo}, \mathrm{Zn}$ & $\mathrm{Te}$ & \\
\hline$<5$ & $\begin{array}{l}\mathrm{As}, \mathrm{Cu}, \mathrm{Ni}, \\
\mathrm{Ag}, \mathrm{Sb}, \mathrm{Te}, \\
\mathrm{Bi}, \mathrm{Zn}, \mathrm{Pb}\end{array}$ & $\begin{array}{c}\text { As, Ni, Ag, } \\
\text { Se, } \mathrm{Sb}, \mathrm{Mo}, \\
\text { Te, Bi, Pb }\end{array}$ & $\begin{array}{c}\mathrm{Au}, \mathrm{Cu}, \mathrm{Se}, \\
\mathrm{Sb}, \mathrm{Mo}, \mathrm{Bi}, \\
\mathrm{Zn}, \mathrm{Pb}\end{array}$ & & $\begin{array}{c}\mathrm{Au}, \mathrm{As}, \mathrm{Cu}, \mathrm{Ni} \\
\mathrm{Ag}, \mathrm{Se}, \mathrm{Sb}, \mathrm{Mo} \\
\mathrm{Bi}, \mathrm{Zn}, \mathrm{Pb}\end{array}$ & $\mathrm{Te}$ \\
\hline
\end{tabular}

Table 5. Mobile forms of gold and pathfinder elements in surface sediments in the Piilola prospecting area.

\begin{tabular}{|c|c|c|c|c|c|c|}
\hline $\begin{array}{c}\text { Form } \\
\text { Percentage }\end{array}$ & Water-Soluble & $\begin{array}{c}\text { Loosely } \\
\text { Adsorbed }\end{array}$ & $\begin{array}{c}\text { Strongly } \\
\text { Adsorbed }\end{array}$ & $\begin{array}{c}\text { Bound to } \\
\text { Organic } \\
\text { Matter }\end{array}$ & $\begin{array}{c}\text { Bound to } \\
\text { Carbonates }\end{array}$ & $\begin{array}{c}\text { Bound to Fe } \\
\text { and Mn (Hydr-) } \\
\text { Oxides }\end{array}$ \\
\hline$>50$ & $\mathrm{Au}$ & $\mathrm{Zn}$ & & Mo & & $\begin{array}{c}\mathrm{As}, \mathrm{Cu}, \mathrm{Ni}, \mathrm{Ag} \\
\mathrm{Bi}, \mathrm{Pb}\end{array}$ \\
\hline $30-50$ & & & & $\mathrm{Au}, \mathrm{Sb}$ & & Se \\
\hline $15-30$ & Se & & $\begin{array}{l}\text { As, Se, } \\
\text { Mo, Te }\end{array}$ & $\begin{array}{l}\mathrm{Ag}, \mathrm{Se}, \\
\mathrm{Te}, \mathrm{Pb}\end{array}$ & & $\mathrm{Sb}, \mathrm{Mo}, \mathrm{Te}, \mathrm{Zn}$ \\
\hline 5-15 & $\mathrm{Sb}, \mathrm{Te}, \mathrm{Bi}$ & $\mathrm{Se}, \mathrm{Te}$ & $\begin{array}{l}\mathrm{Cu}, \mathrm{Ni}, \\
\mathrm{Sb}, \mathrm{Zn}\end{array}$ & $\begin{array}{c}\text { As, Cu, } \\
\mathrm{Ni}, \mathrm{Bi}, \mathrm{Zn}\end{array}$ & $\mathrm{Te}$ & \\
\hline$<5$ & $\begin{array}{c}\mathrm{As}, \mathrm{Cu}, \mathrm{Ni}, \\
\mathrm{Ag}, \mathrm{Mo}, \\
\mathrm{Zn}, \mathrm{Pb}\end{array}$ & $\begin{array}{l}\mathrm{Au}, \mathrm{As}, \mathrm{Cu}, \\
\mathrm{Ni}, \mathrm{Ag}, \mathrm{Sb}, \\
\mathrm{Mo}, \mathrm{Bi}, \mathrm{Pb}\end{array}$ & $\begin{array}{c}\mathrm{Au}, \mathrm{Ag} \\
\mathrm{Bi}, \mathrm{Pb}\end{array}$ & & $\begin{array}{c}\mathrm{Au}, \mathrm{As}, \mathrm{Cu}, \mathrm{Ni} \\
\mathrm{Ag}, \mathrm{Se} \mathrm{Sb}, \mathrm{Mo} \\
\mathrm{Bi}, \mathrm{Zn}, \mathrm{Pb}\end{array}$ & $\mathrm{Au}$ \\
\hline
\end{tabular}

The total content of the mobile forms for all of the studied elements is a significant percentage of their total concentrations in soil and moraine (Tables 6 and 7). Here and below, the mobile forms are understood as a concentration of all the forms leached from steps 1 to 6 of the sequential extraction procedure: water-soluble, loosely and strongly adsorbed, and bound to organic matter, to carbonates and to iron and manganese (hydr-)oxides. For example, the proportions of gold's mobile forms vary from 59 to $96 \%$ in the Piilola area and from 40 to $72 \%$ at Novye Pesky; moreover, the percentages of the mobile form are lowest in horizon B, compared to E and C in profiles No. 1, No. 2, No. 4, and the largest in No. 3 and No. 10. The percentages of the mobile form of gold are lower in the moraine than in the overlying soil horizon $C$ of all the profiles of the Piilola prospecting area. The percentages of $\mathrm{Bi}, \mathrm{As}, \mathrm{Mo}$, and $\mathrm{Zn}$ mobile forms are very significant in both regions and more than $50 \%$. Ag, Te, and $\mathrm{Cu}$ are also predominantly in their mobile form, the proportions of which are higher than $50 \%$ in the Piilola area, but these tendencies are characterized by other trends at Novye Peski: the mobile form percentages depend on the place and the depth of sampling, and, in general, amount to more than $30 \%$ for those elements. It can also be noted that the elements studied in the soil of Novye Peski are less "mobile" than in the Piilola area because the percentages of mobile forms for some of them are slightly lower. $\mathrm{Ni}$, Se, and $\mathrm{Pb}$ are the least mobile elements in both regions. 
Table 6. Percentages of mobile forms of elements in surface sediments in the Piilola area. MF-mobile form (ppm); TQ—-total quantity (sum of element concentration in all extracts, ppm); \%—mobile form percentage from the total quantity.

\begin{tabular}{|c|c|c|c|c|c|c|c|c|c|c|c|c|c|}
\hline \multirow{2}{*}{ Profile } & \multirow{2}{*}{ Horizon } & \multicolumn{3}{|c|}{$\mathrm{Au}$} & \multicolumn{3}{|c|}{ Bi } & \multicolumn{3}{|c|}{ Ag } & \multicolumn{3}{|c|}{ Te } \\
\hline & & MF & TQ & $\%$ & MF & TQ & $\%$ & MF & TQ & $\%$ & MF & TQ & $\%$ \\
\hline \multirow{4}{*}{1} & E & 0.0387 & 0.0403 & 95.9 & 0.062 & 0.094 & 65.8 & 0.551 & 0.699 & 78.7 & 0.078 & 0.091 & 85.7 \\
\hline & Bhf & 0.0265 & 0.0449 & 58.9 & 0.100 & 0.141 & 71.0 & 0.609 & 0.722 & 84.4 & 0.091 & 0.104 & 87.5 \\
\hline & $\mathrm{C}$ & 0.0150 & 0.0167 & 89.7 & 0.050 & 0.086 & 58.8 & 0.374 & 0.467 & 80.1 & 0.046 & 0.065 & 70.0 \\
\hline & M & 0.0068 & 0.0105 & 64.5 & 0.090 & 0.141 & 63.8 & 0.430 & 0.514 & 83.6 & 0.052 & 0.059 & 88.9 \\
\hline \multirow{4}{*}{4} & E & 0.0135 & 0.0155 & 87.0 & 0.084 & 0.104 & 81.1 & 0.553 & 0.631 & 87.7 & 0.013 & 0.013 & 100.0 \\
\hline & Bhf & 0.0137 & 0.0165 & 83.2 & 0.150 & 0.216 & 69.3 & 0.757 & 0.839 & 90.3 & 0.182 & 0.182 & 100.0 \\
\hline & $\mathrm{C}$ & 0.0192 & 0.0226 & 85.1 & 0.135 & 0.175 & 77.3 & 0.665 & 0.753 & 88.2 & 0.046 & 0.046 & 100.0 \\
\hline & M & 0.0227 & 0.0321 & 70.8 & 13.217 & 13.867 & 95.3 & 0.769 & 0.876 & 87.8 & 0.365 & 0.423 & 86.2 \\
\hline \multirow{4}{*}{10} & $\mathrm{E}$ & 0.0090 & 0.0114 & 79.1 & 0.095 & 0.135 & 70.5 & 0.516 & 0.613 & 84.2 & 0.026 & 0.046 & 57.2 \\
\hline & Bhf & 0.0097 & 0.0114 & 85.1 & 0.112 & 0.151 & 73.9 & 0.637 & 0.733 & 87.0 & 0.091 & 0.111 & 82.4 \\
\hline & C & 0.0113 & 0.0135 & 83.6 & 0.121 & 0.172 & 70.1 & 0.698 & 0.771 & 90.6 & 0.052 & 0.052 & 100.0 \\
\hline & M & 0.0079 & 0.0116 & 67.8 & 0.377 & 0.423 & 89.0 & 0.819 & 0.945 & 86.7 & 0.117 & 0.117 & 100.0 \\
\hline \multirow{2}{*}{ Profile } & \multirow{2}{*}{ Horizon } & \multicolumn{3}{|c|}{$\mathrm{Ni}$} & \multicolumn{3}{|c|}{$\mathrm{Zn}$} & \multicolumn{3}{|c|}{ Se } & \multicolumn{3}{|c|}{ Mo } \\
\hline & & MF & TQ & $\%$ & MF & TQ & $\%$ & MF & TQ & $\%$ & MF & TQ & $\%$ \\
\hline \multirow{4}{*}{1} & $\mathrm{E}$ & 2.7 & 10.5 & 25.5 & 149.6 & 161.5 & 92.7 & 0.467 & 0.813 & 57.4 & 1.6 & 1.8 & 94.1 \\
\hline & Bhf & 21.5 & 40.0 & 53.8 & 168.6 & 204.0 & 82.6 & 0.663 & 1.039 & 63.8 & 1.9 & 2.3 & 82.2 \\
\hline & $\mathrm{C}$ & 13.7 & 27.7 & 49.2 & 235.2 & 261.6 & 89.9 & 0.536 & 0.902 & 59.4 & 1.6 & 1.7 & 91.7 \\
\hline & M & 30.5 & 57.8 & 52.8 & 135.7 & 166.5 & 81.5 & 0.808 & 1.830 & 44.2 & 1.8 & 2.0 & 90.2 \\
\hline \multirow{4}{*}{4} & $E$ & 2.3 & 5.8 & 40.0 & 116.8 & 126.6 & 92.2 & 0.511 & 0.811 & 63.0 & 1.5 & 1.7 & 91.7 \\
\hline & Bhf & 12.9 & 23.0 & 56.1 & 178.7 & 197.0 & 90.7 & 0.821 & 1.251 & 65.6 & 2.3 & 2.5 & 93.9 \\
\hline & $\mathrm{C}$ & 17.9 & 36.1 & 49.4 & 138.3 & 166.9 & 82.9 & 0.639 & 2.206 & 29.0 & 1.5 & 1.7 & 88.3 \\
\hline & M & 7.3 & 13.0 & 56.3 & 119.4 & 134.3 & 88.9 & 0.816 & 1.123 & 72.6 & 2.8 & 3.1 & 92.0 \\
\hline \multirow{4}{*}{10} & $\mathrm{E}$ & 4.8 & 45.3 & 10.7 & 94.9 & 118.0 & 80.4 & 0.423 & 0.703 & 60.1 & 1.6 & 1.7 & 92.1 \\
\hline & Bhf & 80.6 & 98.6 & 81.7 & 144.7 & 168.2 & 86.1 & 0.710 & 1.093 & 64.9 & 1.6 & 1.8 & 91.6 \\
\hline & $\mathrm{C}$ & 83.7 & 135.4 & 61.8 & 138.2 & 164.2 & 84.2 & 0.634 & 2.064 & 30.7 & 1.6 & 1.8 & 91.5 \\
\hline & M & 92.4 & 153.1 & 60.3 & 185.3 & 217.7 & 85.2 & 0.646 & 0.993 & 65.1 & 2.5 & 2.8 & 89.6 \\
\hline \multirow{2}{*}{ Profile } & \multirow{2}{*}{ Horizon } & \multicolumn{3}{|c|}{ As } & & $\mathrm{Cu}$ & & & $\mathrm{Sb}$ & & & $\mathrm{Pb}$ & \\
\hline & & MF & TQ & $\%$ & MF & TQ & $\%$ & MF & TQ & $\%$ & MF & TQ & $\%$ \\
\hline & E & 2.8 & 3.1 & 90.4 & 5.4 & 7.1 & 77.0 & 2.5 & 2.8 & 88.6 & 4.5 & 12.4 & 36.4 \\
\hline & Bhf & 71.7 & 76.3 & 94.0 & 16.2 & 17.9 & 90.8 & 2.3 & 5.2 & 43.8 & 5.6 & 12.4 & 45.2 \\
\hline 1 & $\mathrm{C}$ & 5.4 & 5.7 & 95.5 & 18.3 & 23.0 & 79.7 & 1.4 & 1.6 & 85.8 & 3.6 & 11.5 & 31.5 \\
\hline & M & 15.5 & 16.0 & 96.9 & 29.5 & 33.8 & 87.4 & 1.3 & 1.5 & 84.6 & 6.0 & 12.0 & 50.2 \\
\hline & $\mathrm{E}$ & 2.8 & 3.2 & 88.4 & 29.9 & 30.7 & 97.4 & 1.6 & 1.7 & 88.9 & 4.6 & 9.4 & 49.5 \\
\hline & Bhf & 41.9 & 42.5 & 98.5 & 110.4 & 111.6 & 98.9 & 2.3 & 2.9 & 80.5 & 9.3 & 15.4 & 60.5 \\
\hline 4 & $\mathrm{C}$ & 36.0 & 36.7 & 98.0 & 16.9 & 18.7 & 90.5 & 1.7 & 2.0 & 84.2 & 3.4 & 8.7 & 38.4 \\
\hline & M & 44.3 & 45.6 & 97.1 & 13.1 & 15.1 & 86.5 & 1.2 & 1.4 & 88.3 & 9.3 & 17.6 & 52.5 \\
\hline & E & 19.3 & 23.1 & 83.8 & 4.6 & 5.9 & 79.3 & 1.4 & 1.7 & 78.7 & 17.5 & 24.2 & 72.4 \\
\hline & Bhf & 70.0 & 71.6 & 97.8 & 15.7 & 19.8 & 79.2 & 1.6 & 1.7 & 91.8 & 6.1 & 11.8 & 51.8 \\
\hline 10 & C & 131.2 & 132.7 & 98.9 & 20.4 & 23.7 & 86.1 & 1.6 & 1.8 & 91.5 & 3.4 & 7.4 & 45.5 \\
\hline & $\mathrm{M}$ & 118.6 & 120.7 & 98.2 & 33.0 & 38.2 & 86.3 & 1.5 & 2.7 & 54.9 & 8.1 & 13.4 & 60.7 \\
\hline
\end{tabular}


Table 7. Percentages of mobile forms of elements in surface sediments in the Novye Peski area. MF-mobile form (ppm); TQ—-total quantity (sum of element concentration in all extracts, ppm); $\%$-mobile form percentage from the total quantity.

\begin{tabular}{|c|c|c|c|c|c|c|c|c|c|c|c|c|c|}
\hline \multirow{2}{*}{ Profile } & \multirow{2}{*}{ Horizon } & \multicolumn{3}{|c|}{$\mathrm{Au}$} & \multicolumn{3}{|c|}{$\mathbf{B i}$} & \multicolumn{3}{|c|}{ Ag } & \multicolumn{3}{|c|}{$\mathrm{Te}$} \\
\hline & & MF & TQ & $\%$ & MF & TQ & $\%$ & MF & TQ & $\%$ & MF & TQ & $\%$ \\
\hline \multirow{3}{*}{1} & $\mathrm{E}$ & 0.0051 & 0.0077 & 65.8 & 0.062 & 0.109 & 56.8 & 0.200 & 0.467 & 42.9 & 0.10 & 0.15 & 67.6 \\
\hline & $\mathrm{Bf}$ & 0.0021 & 0.0043 & 48.1 & 0.081 & 0.109 & 74.7 & 0.061 & 0.296 & 20.8 & 0.10 & 0.10 & 100.0 \\
\hline & $\mathrm{C}$ & 0.0041 & 0.0058 & 71.0 & 0.244 & 0.312 & 78.3 & 0.029 & 0.153 & 19.3 & 0.25 & 0.25 & 100.0 \\
\hline \multirow{3}{*}{2} & $\mathrm{E}$ & 0.0036 & 0.0053 & 68.1 & 0.056 & 0.099 & 56.3 & 0.726 & 0.924 & 78.6 & 0.14 & 0.14 & 100.0 \\
\hline & $\mathrm{Bf}$ & 0.0028 & 0.0069 & 40.3 & 0.065 & 0.086 & 75.1 & 2.505 & 2.575 & 97.3 & 0.19 & 0.19 & 100.0 \\
\hline & $\mathrm{C}$ & 0.0058 & 0.0099 & 58.8 & 0.072 & 0.099 & 72.7 & 0.002 & 0.080 & 2.0 & 0.09 & 0.15 & 63.1 \\
\hline \multirow{3}{*}{3} & $\mathrm{E}$ & 0.0028 & 0.0056 & 50.2 & 0.027 & 0.051 & 52.9 & 0.062 & 0.126 & 49.2 & 0.18 & 0.18 & 100.0 \\
\hline & $\mathrm{Bf}$ & 0.0071 & 0.0099 & 71.8 & 0.079 & 0.143 & 55.0 & 0.067 & 0.244 & 27.5 & $<0.0003$ & 0.06 & 0.0 \\
\hline & $\mathrm{C}$ & 0.0049 & 0.0077 & 64.0 & 0.036 & 0.048 & 74.5 & 0.014 & 0.041 & 34.2 & 0.05 & 0.17 & 31.6 \\
\hline \multirow{2}{*}{ Profile } & \multirow{2}{*}{ Horizon } & \multicolumn{3}{|c|}{$\mathrm{Ni}$} & \multicolumn{3}{|c|}{$\mathrm{Zn}$} & \multicolumn{3}{|c|}{ Se } & \multicolumn{3}{|c|}{ Mo } \\
\hline & & MF & TQ & $\%$ & MF & TQ & $\%$ & MF & TQ & $\%$ & MF & TQ & $\%$ \\
\hline \multirow{3}{*}{1} & $E$ & 1.79 & 16.61 & 10.8 & 111.89 & 129.86 & 86.2 & 0.28 & 3.55 & 8.0 & 1.70 & 2.70 & 63.1 \\
\hline & $\mathrm{Bf}$ & 15.19 & 23.82 & 63.8 & 80.00 & 97.90 & 81.7 & 0.61 & 1.14 & 53.2 & 2.97 & 3.36 & 88.3 \\
\hline & $\mathrm{C}$ & 10.09 & 21.10 & 47.8 & 148.10 & 186.68 & 79.3 & 0.49 & 0.89 & 55.5 & 2.84 & 3.09 & 91.9 \\
\hline \multirow{3}{*}{2} & $E$ & 6.14 & 18.65 & 32.9 & 141.74 & 160.92 & 88.1 & 0.16 & 0.42 & 38.5 & 6.63 & 6.93 & 95.7 \\
\hline & $\mathrm{Bf}$ & 17.74 & 28.01 & 63.3 & 100.36 & 114.75 & 87.5 & 0.23 & 0.48 & 48.9 & 3.53 & 4.07 & 86.9 \\
\hline & $\mathrm{C}$ & 15.23 & 23.02 & 66.2 & 85.69 & 106.50 & 80.5 & 0.26 & 0.45 & 57.3 & 1.71 & 2.72 & 63.0 \\
\hline \multirow{3}{*}{3} & $\mathrm{E}$ & 3.47 & 12.85 & 27.0 & 65.03 & 77.00 & 84.4 & 0.15 & 0.51 & 28.9 & 2.16 & 2.48 & 87.3 \\
\hline & $\mathrm{Bf}$ & 21.60 & 32.24 & 67.0 & 228.78 & 250.36 & 91.4 & 0.37 & 0.95 & 38.8 & 2.22 & 2.44 & 90.9 \\
\hline & $\mathrm{C}$ & 6.22 & 19.95 & 31.2 & 55.53 & 73.92 & 75.1 & 0.14 & 0.27 & 50.7 & 2.06 & 2.18 & 94.2 \\
\hline \multirow{2}{*}{ Profile } & \multirow{2}{*}{ Horizon } & \multicolumn{3}{|c|}{ As } & \multicolumn{3}{|c|}{$\mathrm{Cu}$} & \multicolumn{3}{|c|}{$\mathrm{Sb}$} & \multicolumn{3}{|c|}{$\mathrm{Pb}$} \\
\hline & & MF & TQ & $\%$ & MF & TQ & $\%$ & MF & TQ & $\%$ & MF & TQ & $\%$ \\
\hline \multirow{3}{*}{1} & $\mathrm{E}$ & 2.97 & 3.80 & 78.2 & 0.75 & 17.67 & 4.2 & 0.74 & 1.73 & 43.0 & 4.20 & 12.49 & 33.6 \\
\hline & $\mathrm{Bf}$ & 20.53 & 21.61 & 95.0 & 10.50 & 18.07 & 58.1 & 9.82 & 10.92 & 89.9 & 5.14 & 12.28 & 41.9 \\
\hline & $\mathrm{C}$ & 100.51 & 102.61 & 98.0 & 37.62 & 43.48 & 86.5 & 1.76 & 2.16 & 81.4 & 7.68 & 15.26 & 50.3 \\
\hline \multirow{3}{*}{2} & E & 2.31 & 2.71 & 85.3 & 4.75 & 9.62 & 49.4 & 1.06 & 1.45 & 73.4 & 6.82 & 16.79 & 40.6 \\
\hline & $\mathrm{Bf}$ & 5.25 & 5.57 & 94.2 & 12.10 & 16.74 & 72.3 & 5.28 & 6.07 & 87.0 & 5.11 & 12.49 & 41.0 \\
\hline & $\mathrm{C}$ & 1.27 & 2.32 & 54.9 & 20.69 & 25.27 & 81.9 & 1.35 & 2.04 & 66.1 & 6.46 & 12.66 & 51.1 \\
\hline & $\mathrm{E}$ & 1.93 & 2.27 & 84.8 & 0.84 & 2.62 & 32.2 & 1.68 & 2.33 & 71.9 & 4.47 & 14.95 & 29.9 \\
\hline 3 & $\mathrm{Bf}$ & 5.45 & 5.83 & 93.5 & 15.46 & 22.08 & 70.0 & 2.28 & 3.24 & 70.5 & 28.22 & 37.97 & 74.3 \\
\hline & $\mathrm{C}$ & 0.64 & 1.03 & 62.4 & 6.57 & 9.89 & 66.4 & 2.12 & 2.53 & 83.6 & 3.71 & 11.33 & 32.7 \\
\hline
\end{tabular}

\subsection{Analysis of Gold and Pathfinder Elements in Humic and Fulvic Acids}

The extracts of HA and FA were prepared from surface sediment samples of the study areas for the analysis for gold and pathfinder concentrations. The results of that analysis are presented in Tables 8-11. The majority of the studied elements interact with both HA and FA, and only some elements (Ag; Mo in the Piilola area and As at Novye Peski) were detected only in extracts of one type of organic matter. Also, we can discern a group of elements bound preferably to FA or HA in surface sediments. $\mathrm{Au}, \mathrm{Ni}, \mathrm{Bi}$, and $\mathrm{Ag}$ are bound preferably to $\mathrm{HA}$ and $\mathrm{As}, \mathrm{Cu}, \mathrm{Pb}, \mathrm{Te}, \mathrm{Se}$, and $\mathrm{Mo}$ to $\mathrm{FA}$ at both study areas, but $\mathrm{Zn}$ and $\mathrm{Sb}$ bound to HA at Novye Peski and to FA in the Piilola area. 
Table 8. Concentration of humic acid (HA) and fluvic acid (FA) carbon in surface sediments at Novye Peski.

\begin{tabular}{cccc}
\hline Profile & Horizon & HA, $\%$ & FA, $\%$ \\
\hline \multirow{3}{*}{ No. 1} & E & 0.41 & 1.07 \\
& Bf & 0.25 & 1.13 \\
& C & 0.15 & 0.39 \\
\hline \multirow{3}{*}{ No. 2} & E & 0.15 & 0.29 \\
& Bf & 0.16 & 1.09 \\
& C & 0.10 & 0.00 \\
\hline \multirow{2}{*}{ No. 3 } & E & 0.25 & 0.25 \\
& Bf & 0.16 & 0.67 \\
& C & 0.10 & 0.05 \\
\hline
\end{tabular}

Table 9. Concentration of HA and FA carbon in surface sediments in the Piilola prospecting area.

\begin{tabular}{cccc}
\hline Profile & Horizon & HA, $\%$ & FA, $\%$ \\
\hline \multirow{4}{*}{ No. 1} & E & 0.24 & 0.66 \\
& Bhf & 0.15 & 1.05 \\
& C & 0.17 & 0.01 \\
& M & 0.10 & 0.10 \\
\hline \multirow{5}{*}{ No. 4} & E & 0.36 & 0.33 \\
& Bhf & 0.50 & 5.50 \\
& C & 0.18 & 0.78 \\
No. 10 & M & 0.66 & 2.54 \\
& E & 0.29 & 0.01 \\
& Bhf & 1.25 & 1.2 \\
& C & 0.25 & 0.74 \\
& M & 0.25 & 1.43 \\
\hline
\end{tabular}

Table 10. Concentrations of elements in HA and FA extracts at Novye Peski.

\begin{tabular}{|c|c|c|c|c|c|c|c|c|c|}
\hline \multirow{2}{*}{ Profile } & \multirow{2}{*}{ Horizon } & \multicolumn{2}{|c|}{$\mathrm{Au}$} & \multicolumn{2}{|c|}{$\mathrm{Ni}$} & \multicolumn{2}{|c|}{ Se } & \multicolumn{2}{|c|}{$\mathrm{Sb}$} \\
\hline & & HA & FA & HA & FA & HA & FA & HA & FA \\
\hline \multirow{3}{*}{ No. 1} & $\mathrm{E}$ & 0.0003 & 0.0004 & 0.412 & 0.313 & 0.028 & $<0.006$ & 0.006 & $<0.0001$ \\
\hline & $\mathrm{Bf}$ & 0.0055 & 0.0012 & 0.187 & 0.108 & 0.014 & 0.028 & 0.113 & 0.028 \\
\hline & C & 0.00005 & 0.0008 & $<0.001$ & $<0.001$ & 0.075 & 0.039 & $<0.0001$ & $<0.0001$ \\
\hline \multirow{3}{*}{ No. 2} & $E$ & 0.0026 & 0.0001 & 0.009 & 0.434 & $<0.006$ & 0.056 & 0.0002 & $<0.0001$ \\
\hline & $\mathrm{Bf}$ & 0.0008 & $<0.00001$ & 0.072 & 0.302 & $<0.006$ & 0.167 & 0.003 & $<0.0001$ \\
\hline & $\mathrm{C}$ & $<0.00001$ & 0.0007 & $<0.001$ & 0.225 & $<0.006$ & 0.056 & $<0.0001$ & $<0.0001$ \\
\hline \multirow{3}{*}{ No. 3} & $\mathrm{E}$ & 0.0009 & 0.0002 & 0.492 & 0.165 & $<0.006$ & $<0.006$ & 0.064 & 0.156 \\
\hline & $\mathrm{Bf}$ & $<0.00001$ & 0.0022 & 0.258 & 0.165 & 0.014 & $<0.006$ & 0.015 & $<0.0001$ \\
\hline & $\mathrm{C}$ & 0.0009 & $<0.00001$ & 0.191 & $<0.001$ & $<0.006$ & $<0.006$ & 0.03 & $<0.0001$ \\
\hline \multirow{2}{*}{ Profile } & \multirow{2}{*}{ Horizon } & \multicolumn{2}{|c|}{ Ag } & \multicolumn{2}{|c|}{$\mathrm{Zn}$} & \multicolumn{2}{|c|}{$\mathrm{Cu}$} & \multicolumn{2}{|c|}{ As } \\
\hline & & HA & FA & HA & FA & HA & FA & HA & FA \\
\hline \multirow{3}{*}{ No. 1} & $E$ & 0.1020 & $<0.0005$ & 0.075 & 0.396 & $<0.006$ & 0.622 & 0.63 & $<0.04$ \\
\hline & $\mathrm{Bf}$ & 0.0100 & $<0.0005$ & $<0.003$ & 1.307 & $<0.006$ & 8.578 & 0.67 & $<0.04$ \\
\hline & $\mathrm{C}$ & 0.0980 & $<0.0005$ & 0.084 & 4.626 & $<0.006$ & 38.942 & 0.51 & $<0.04$ \\
\hline \multirow{3}{*}{ No. 2} & $\mathrm{E}$ & 0.0020 & $<0.0005$ & 0.003 & 0.339 & $<0.006$ & 0.277 & 0.25 & $<0.04$ \\
\hline & $\mathrm{Bf}$ & $<0.0005$ & $<0.0005$ & 0.018 & 0.761 & $<0.006$ & 0.462 & 0.05 & $<0.04$ \\
\hline & $\mathrm{C}$ & 0.0600 & $<0.0005$ & 0.075 & 5.720 & $<0.006$ & 0.474 & 0.48 & 0.77 \\
\hline \multirow{3}{*}{ No. 3} & $\mathrm{E}$ & 0.1120 & $<0.0005$ & $<0.003$ & 0.223 & $<0.006$ & 0.141 & 1.02 & $<0.04$ \\
\hline & $\mathrm{Bf}$ & 0.0140 & $<0.0005$ & $<0.003$ & 2.659 & $<0.006$ & 1.275 & 0.16 & $<0.04$ \\
\hline & $\mathrm{C}$ & $<0.0005$ & $<0.0005$ & $<0.003$ & 0.675 & $<0.006$ & 0.183 & 0.27 & $<0.04$ \\
\hline
\end{tabular}


Table 10. Cont.

\begin{tabular}{cccccccccc}
\hline \multirow{2}{*}{ Profile } & \multirow{2}{*}{ Horizon } & \multicolumn{2}{c}{ Ag } & \multicolumn{2}{c}{ Zn } & \multicolumn{2}{c}{ Cu } & \multicolumn{3}{c}{ As } \\
\cline { 3 - 10 } & & HA & FA & HA & FA & HA & FA & HA & FA \\
\hline \multirow{2}{*}{ No. 1} & E & 0.1020 & $<0.0005$ & 0.075 & 0.396 & $<0.006$ & 0.622 & 0.63 & $<0.04$ \\
& Bf & 0.0100 & $<0.0005$ & $<0.003$ & 1.307 & $<0.006$ & 8.578 & 0.67 & $<0.04$ \\
& C & 0.0980 & $<0.0005$ & 0.084 & 4.626 & $<0.006$ & 38.942 & 0.51 & $<0.04$ \\
\hline \multirow{3}{*}{ No. 2} & E & 0.0020 & $<0.0005$ & 0.003 & 0.339 & $<0.006$ & 0.277 & 0.25 & $<0.04$ \\
& Bf & $<0.0005$ & $<0.0005$ & 0.018 & 0.761 & $<0.006$ & 0.462 & 0.05 & $<0.04$ \\
& C & 0.0600 & $<0.0005$ & 0.075 & 5.720 & $<0.006$ & 0.474 & 0.48 & 0.77 \\
\hline \multirow{2}{*}{ No. 3 } & E & 0.1120 & $<0.0005$ & $<0.003$ & 0.223 & $<0.006$ & 0.141 & 1.02 & $<0.04$ \\
& Bf & 0.0140 & $<0.0005$ & $<0.003$ & 2.659 & $<0.006$ & 1.275 & 0.16 & $<0.04$ \\
& C & $<0.0005$ & $<0.0005$ & $<0.003$ & 0.675 & $<0.006$ & 0.183 & 0.27 & $<0.04$ \\
\hline
\end{tabular}

Table 11. Concentrations of elements in HA and FA extracts in the Piilola prospecting area.

\begin{tabular}{|c|c|c|c|c|c|c|c|c|c|}
\hline \multirow{2}{*}{ Profile } & \multirow{2}{*}{ Horizon } & \multicolumn{2}{|c|}{$\mathbf{A u}$} & \multicolumn{2}{|c|}{$\mathrm{Ni}$} & \multicolumn{2}{|c|}{ Se } & \multicolumn{2}{|c|}{$\mathrm{Sb}$} \\
\hline & & HA & FA & HA & FA & HA & FA & HA & FA \\
\hline \multirow{4}{*}{ No. 1} & E & 0.0029 & 0.0011 & 0.556 & 0.259 & $<0.006$ & $<0.006$ & 0.058 & 0.370 \\
\hline & Bhf & 0.0004 & 0.0007 & 0.726 & 0.191 & $<0.006$ & 0.613 & 0.056 & 0.230 \\
\hline & $\mathrm{C}$ & $<0.00001$ & $<0.00001$ & $<0.001$ & $<0.001$ & $<0.006$ & 0.007 & $<0.0001$ & 0.037 \\
\hline & $\mathrm{M}$ & $<0.00001$ & $<0.00001$ & $<0.001$ & $<0.001$ & $<0.006$ & $<0.006$ & $<0.0001$ & 0.025 \\
\hline \multirow{4}{*}{ No. 4} & E & $<0.00001$ & $<0.00001$ & 0.985 & $<0.001$ & $<0.006$ & 0.307 & $<0.0001$ & 0.091 \\
\hline & Bhf & 0.0018 & 0.0008 & 0.642 & $<0.001$ & $<0.006$ & 0.307 & $<0.0001$ & 0.660 \\
\hline & $\mathrm{C}$ & $<0.00001$ & $<0.00001$ & 0.046 & $<0.001$ & $<0.006$ & 0.140 & $<0.0001$ & $<0.0001$ \\
\hline & M & 0.0002 & 0.0005 & 0.554 & $<0.001$ & $<0.006$ & 0.279 & 0.061 & 0.261 \\
\hline \multirow{4}{*}{ No. 10} & $\mathrm{E}$ & $<0.00001$ & $<0.00001$ & 0.247 & $<0.001$ & $<0.006$ & 0.157 & 0.009 & 0.025 \\
\hline & Bhf & $<0.00001$ & 0.0003 & 0.174 & 0.145 & $<0.006$ & 0.139 & 0.014 & 0.054 \\
\hline & $\mathrm{C}$ & $<0.00001$ & $<0.00001$ & $<0.001$ & 0.559 & $<0.006$ & 0.090 & $<0.0001$ & 0.005 \\
\hline & M & $<0.00001$ & $<0.00001$ & 0.454 & 0.704 & $<0.006$ & $<0.006$ & 0.041 & 0.082 \\
\hline \multirow{2}{*}{ Profile } & \multirow{2}{*}{ Horizon } & \multicolumn{2}{|c|}{$\mathrm{Ag}$} & \multicolumn{2}{|c|}{$\mathrm{Zn}$} & \multicolumn{2}{|c|}{$\mathrm{Cu}$} & \multicolumn{2}{|c|}{ As } \\
\hline & & HA & FA & HA & FA & HA & FA & HA & FA \\
\hline \multirow{4}{*}{ No. 1} & $\mathrm{E}$ & 0.051 & $<0.0005$ & 0.086 & 0.483 & $<0.006$ & 0.666 & 0.62 & 65.62 \\
\hline & Bhf & 0.007 & $<0.0005$ & 0.004 & 1.691 & 0.133 & 24.371 & $<0.04$ & 1.71 \\
\hline & $\mathrm{C}$ & $<0.0005$ & $<0.0005$ & $<0.003$ & $<0.003$ & $<0.006$ & 2.011 & $<0.04$ & 65.62 \\
\hline & M & $<0.0005$ & $<0.0005$ & $<0.003$ & 0.748 & 0.105 & 0.105 & $<0.04$ & $<0.04$ \\
\hline \multirow{4}{*}{ No. 4} & $E$ & 0.023 & $<0.0005$ & 0.150 & $<0.003$ & 0.036 & 0.271 & 0.356 & 9.45 \\
\hline & Bhf & 0.042 & $<0.0005$ & 0.164 & 0.761 & 0.079 & 17.223 & 0.325 & 12.23 \\
\hline & $\mathrm{C}$ & $<0.0005$ & $<0.0005$ & 0.128 & 0.623 & 0.190 & 21.172 & $<0.04$ & 1.95 \\
\hline & M & 0.313 & $<0.0005$ & 0.218 & 1.762 & 0.188 & 21.911 & 1.34 & 4.73 \\
\hline \multirow{4}{*}{ No. 10} & $\mathrm{E}$ & 0.004 & $<0.0005$ & 0.075 & $<0.003$ & 0.096 & 4.338 & 0.393 & $<0.04$ \\
\hline & Bhf & 0.017 & $<0.0005$ & 0.041 & 1.502 & 0.167 & 24.504 & $<0.04$ & 1.755 \\
\hline & $\mathrm{C}$ & $<0.0005$ & $<0.0005$ & $<0.003$ & 1.026 & 0.575 & 103.601 & $<0.04$ & 1.965 \\
\hline & M & 0.062 & $<0.0005$ & 0.129 & 0.412 & 0.262 & 47.769 & 0.75 & 3.46 \\
\hline \multirow{2}{*}{ Profile } & \multirow{2}{*}{ Horizon } & \multicolumn{2}{|c|}{ Mo } & \multicolumn{2}{|c|}{$\mathrm{Te}$} & \multicolumn{2}{|c|}{$\mathrm{Pb}$} & F & \\
\hline & & HA & FA & HA & FA & HA & FA & HA & FA \\
\hline & $E$ & $<0.003$ & 0.021 & 0.025 & $<0.0003$ & $<0.001$ & 0.483 & $<0.0005$ & 0.0106 \\
\hline & Bhf & $<0.003$ & 0.046 & $<0.0003$ & $<0.0003$ & $<0.001$ & 0.025 & 0.0033 & $<0.0005$ \\
\hline No. 1 & C & $<0.003$ & 0.011 & $<0.0003$ & $<0.0003$ & $<0.001$ & 0.029 & $<0.0005$ & $<0.0005$ \\
\hline & M & $<0.003$ & 0.168 & $<0.0003$ & $<0.0003$ & $<0.001$ & 0.080 & $<0.0005$ & $<0.0005$ \\
\hline & $E$ & $<0.003$ & 0.042 & $<0.0003$ & $<0.0003$ & $<0.001$ & 1.089 & 0.0381 & 0.0036 \\
\hline & Bhf & $<0.003$ & 0.180 & $<0.0003$ & $<0.0003$ & $<0.001$ & 0.119 & 0.0019 & $<0.0005$ \\
\hline No. 4 & $\mathrm{C}$ & $<0.003$ & 0.071 & $<0.0003$ & 0.005 & $<0.001$ & 0.145 & $<0.0005$ & $<0.0005$ \\
\hline & M & $<0.003$ & 0.429 & $<0.0003$ & 0.057 & 0.006 & 0.162 & 0.6230 & 0.1706 \\
\hline & $E$ & $<0.003$ & 0.003 & 0.325 & $<0.0003$ & $<0.001$ & 0.283 & 0.0766 & $<0.0005$ \\
\hline No 10 & Bhf & $<0.003$ & 0.103 & $<0.0003$ & 0.025 & $<0.001$ & 1.562 & $<0.0005$ & $<0.0005$ \\
\hline No. 10 & C & $<0.003$ & 0.044 & $<0.0003$ & 0.036 & $<0.001$ & 0.016 & $<0.0005$ & $<0.0005$ \\
\hline & M & $<0.003$ & 0.096 & $<0.0003$ & $<0.0003$ & $<0.001$ & 0.040 & 0.0005 & $<0.0005$ \\
\hline
\end{tabular}




\section{Discussion}

As was previously shown, the percentages of the mobile forms of the studied elements are a major part of their total quantity in surface sediments; thus, the mobile forms can be used for the characterization of element concentrations in overburdened areas. Compared to the changes of gold's mobile form concentration from profile No. 3 (out of the mineralized zone) to No. 1 (over the mineralized zone) in the studied soil horizons at Novye Peski, we can observe that it ascends gradually only in the E horizon, and this trend is opposite to that in Bf (Figure 3). The same trend of ascending concentration is seen in the E and Bhf horizons from profile No. 10 to No. 1 in the Piilola prospecting area. The highest content of gold's mobile form was determined in a sample of the Bf horizon at Novye Peski, but that sample was taken in profile, which is out of the mineralized zone. The highest content in the $\mathrm{C}$ horizon is also not over the mineralized zone, but it is in the E horizon.

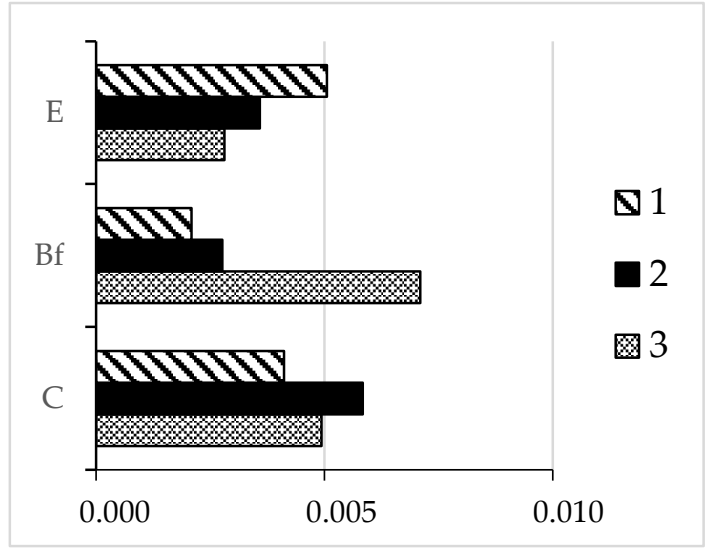

(a)

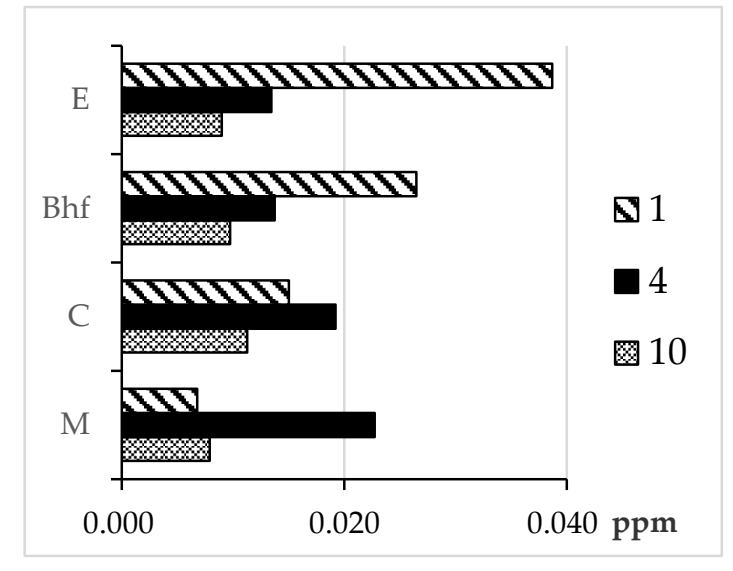

(b)

Figure 3. The changes of gold's mobile form concentration in the studied soil horizons within different profiles: (a) 1-over the mineralized zone, 2-over the circum-ore zone, 3-out of the mineralized zone; (b) 1,4,10-profiles in the Piilola prospecting area.

Thus, we can suggest that the changing of gold's mobile form content in the E soil horizon can point to the mineralization zone. L.N. Antropova [6] stated that chemical elements are in their water-soluble form until and unless they are not bound to organic matter or to Fe and $\mathrm{Mn}$ (hydro-)oxides, and gold is in its water-soluble form in soil over the ore body [28]. According to these facts, it is suggested that the highest water-soluble gold content would appear in the surface sediments overlying the ore body. The highest water-soluble gold content was detected in the E horizon of profile over the mineralized zone at Novye Peski, and the same soil horizon was observed for profile No. 1 in the Piilola prospecting area (Figure 4).

The highest mobile form contents of arsenic and copper are in the C horizon of profile No. 1 at Novye Peski, in the $\mathrm{C}$ horizon and moraine of profile No. 10 for arsenic, and in the Bhf horizon for copper in the Piilola area (Figure 5).

Another main mobile form of gold is bound to organic matter, which is also common for some pathfinders, unlike water-soluble. The variations of $\mathrm{Au}, \mathrm{As}$, and $\mathrm{Cu}$ and the organic carbon ratio in surface sediments are presented in Figure 6. We used the ratio for the standardization of element concentration in the form bound to organic matter, because the samples have a different organic carbon content. As and $\mathrm{Cu}$ were chosen for this consideration because they are the most common pathfinders in the study areas. 


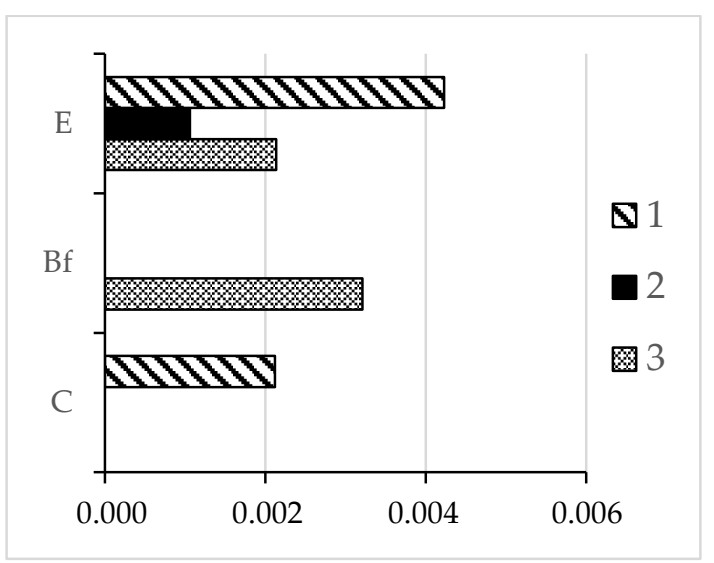

(a)

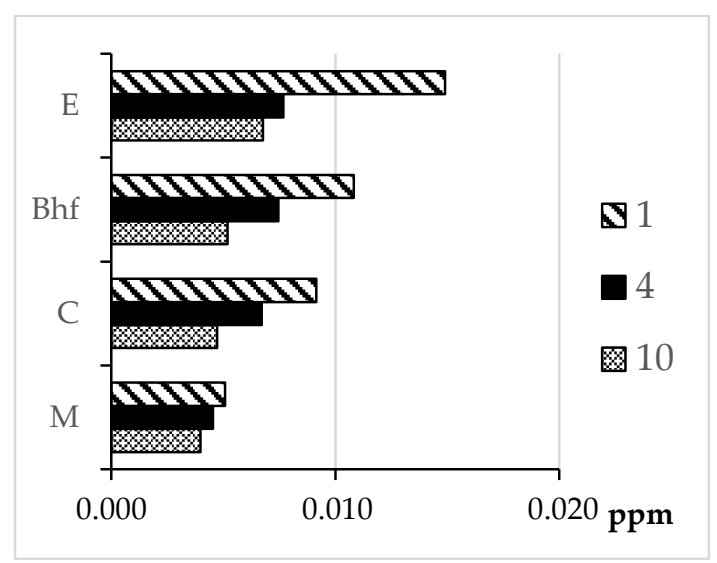

(b)

Figure 4. Water-soluble gold distribution in surface sediment horizons within different profiles: (a) 1-over the mineralized zone, 2-over the circum-ore zone, 3-out of the mineralized zone; (b) 1,4,10-profiles in the Piilola prospecting area.
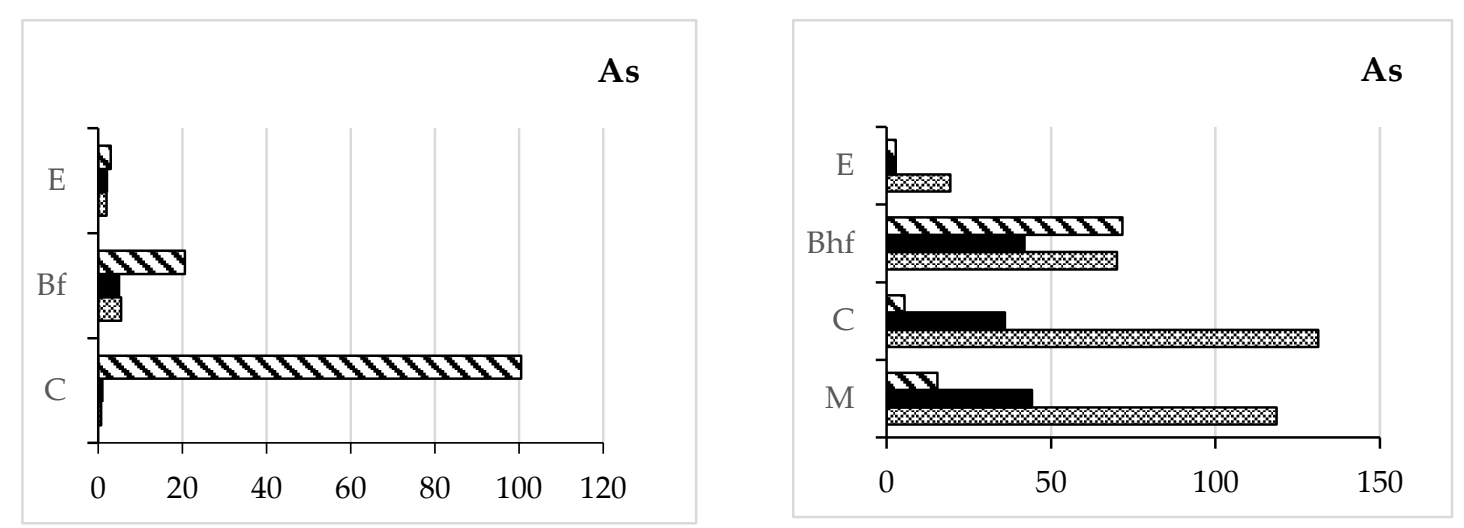

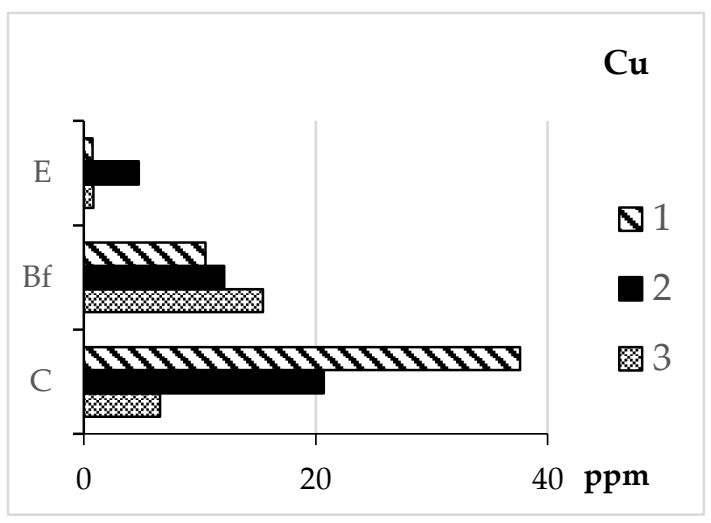

(a)

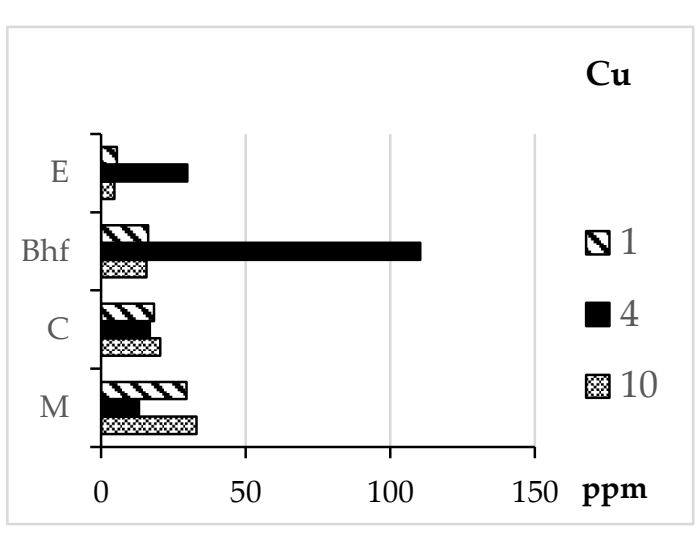

(b)

Figure 5. Distribution of arsenic and copper mobile forms in surface sediment horizons within different profiles: (a) 1-over the mineralized zone, 2-over the circum-ore zone, 3-out of the mineralized zone; (b) 1,4,10-profiles in the Piilola prospecting area. 

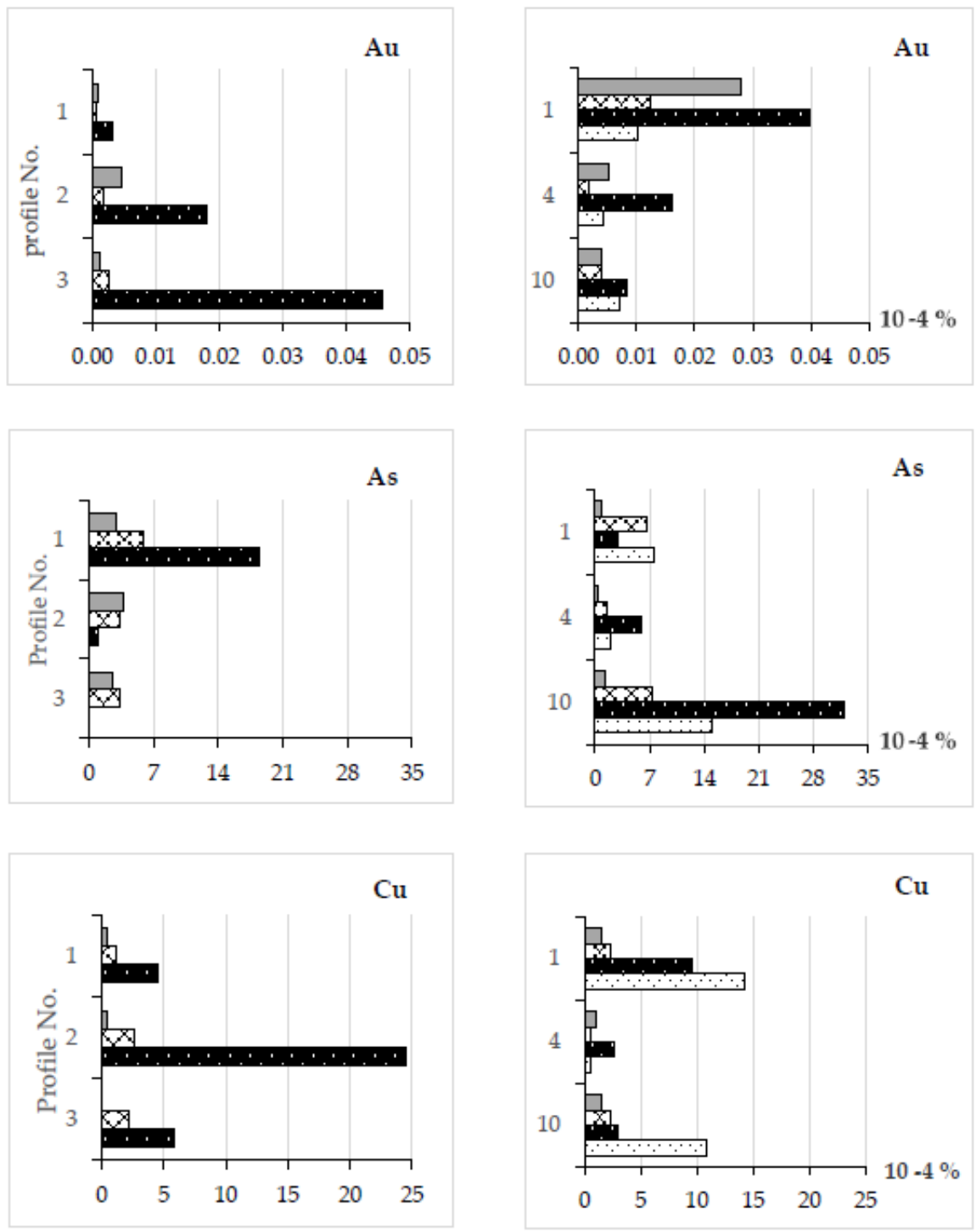

(a)

(b)

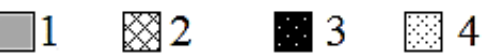

Figure 6. The ratio variation of $\mathrm{Au}, \mathrm{As}$, and $\mathrm{Cu}$ bound to organic matter and carbon in loose sediment horizons in the Novye Peski (a) and Piilola (b) areas. Horizons: 1-E, 2-Bf (Bhf), 3-C, 4-moraine.

The highest $\mathrm{Au} / \mathrm{C}$ ratio is in the $\mathrm{C}$ soil horizon of profile No. 3, and it does not point to the mineralized zone at Novye Peski. Arsenic and copper also have the highest ratio in the $\mathrm{C}$ horizon, but this is in profile No. 2 for copper and only for arsenic in profile No. 1, over the mineralized zone at Novye Peski. The highest ratios of $\mathrm{Au}, \mathrm{As}$, and $\mathrm{Cu}$ bound to organic matter and organic carbon are also common for the lower horizons of overburden in the Piilola prospecting area. The $\mathrm{Au} / \mathrm{C}$ ratio does not point to the mineralized zone, despite the prevalence of the form of gold bound to organic matter. Perhaps, this is a consequence of gold's interaction with various types of organic matter: humic (HA) and fulvic acids (FA), which contribute differently to gold migration and concentration [29-32].

The histograms for the elements bound preferably to HA and to FA are shown in Figure 7. The ratio of gold and HA carbon is highest in profile No. 1 in the Bf soil horizon, of silver is in the C horizon, and of nickel is in the $\mathrm{E}$ and $\mathrm{C}$ soil horizons in profile No. 3. As, $\mathrm{Cu}$, and Mo have the highest ratio in C, but in profile No. 2. None of the analyzed elements have as high a ratio in the Bf horizon as gold, while most of the other elements achieve this in the $C$ horizon, but in different soil profiles. 

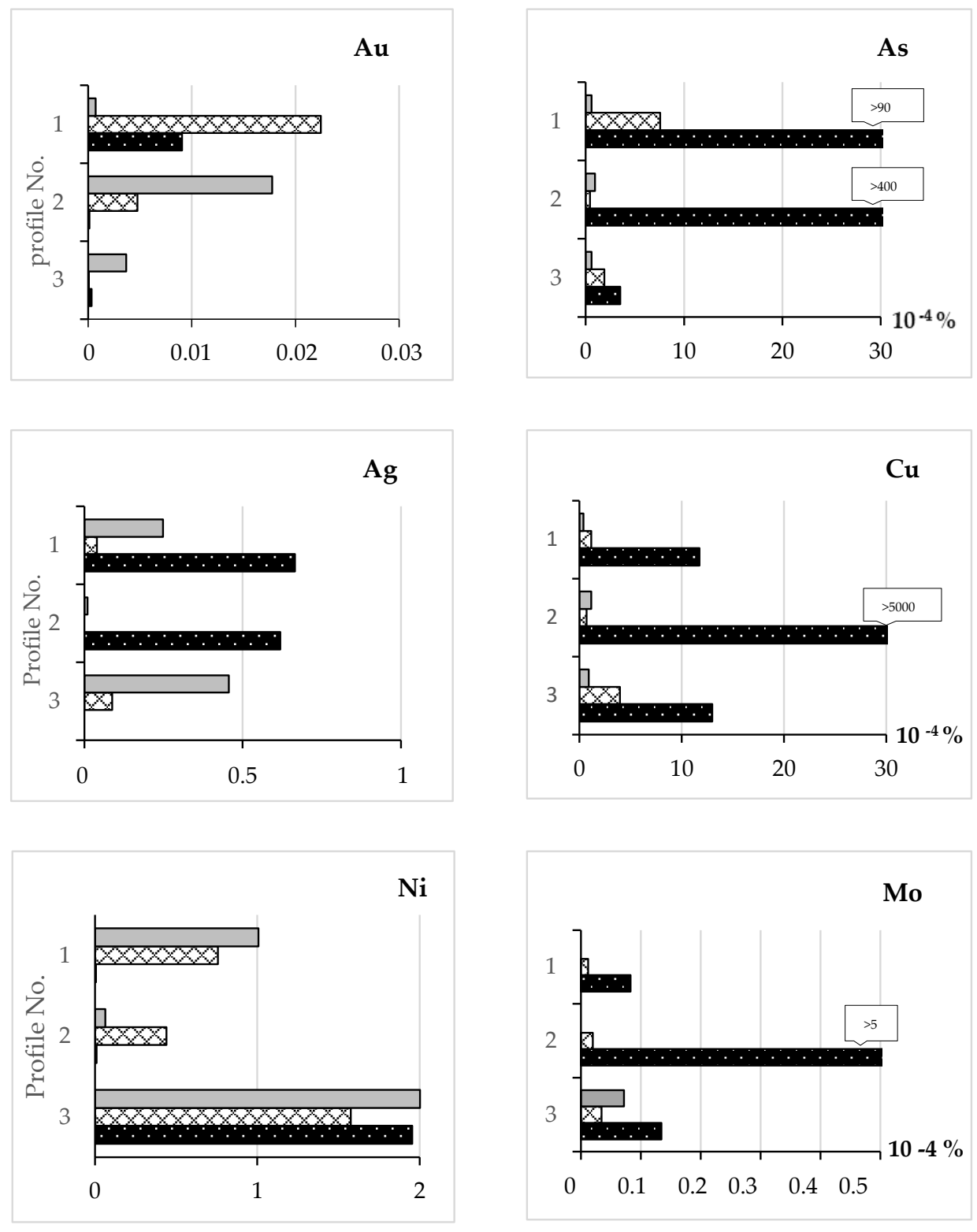

(a)

(b)

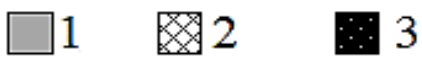

Figure 7. Ratio variation of elements to HA (a) and FA (b) carbon in soil at Novye Peski. Horizons: 1-E, 2-Bf, 3-C.

\section{Conclusions}

The results of the conducted experiment, presented in this paper, demonstrate that gold and pathfinder elements are quite mobile in loose sediments of the studied areas. In addition, the received results demonstrate the main differences between gold and pathfinders in their migration and concentration in surface sediments. Some elements have differences even in a form bound to organic matter due to their interaction with humic or fulvic acids, or with both simultaneously. The forms of gold and pathfinders which point to the mineralized zone are different: water-soluble for gold and predominantly bound to Fe and Mn (hydr-)oxides for pathfinders, and that is why the highest concentration of those forms of the elements is in different horizons in the studied areas: in E horizon 
for gold (0.0042 ppm at Novye Peski, 0.0149 in the Piilola area) and for pathfinders in Bf and C at Novye Peski, Bhf, and moraine in the Piilola area.

Thus, it is very important to determine the features of elements' migration and concentration in a particular type of surface sediment when choosing the elements as pathfinders or when using the geochemical method, based on mobile form analysis, for the prospecting of gold deposits.

Supplementary Materials: The following are available online at http:/ /www.mdpi.com/2075-163X/9/1/34/s1, Figure S1: X-Ray Diffraction results of surface sediments in the Piilola area, Figure S2: Mineralogical characteristic of bedrock in the Piilola area, Figure S3: X-Ray Diffraction results of surface sediments at Novye Peski, Figure S4: Mineralogical characteristic of bedrock at Novye Peski. Table S1: Concentration of different forms of gold in surface sediments (ppm).

Author Contributions: Conceptualization, V.A.K.; methodology, V.A.K. and M.V.C.; investigation, V.A.K.; writing-original draft preparation, V.A.K.; writing—review and editing, V.A.K. and M.V.C.

Funding: This work was supported by the Russian Foundation for Basic Research (grant 16-05-00866). The research was carried out with the equipment of the Resource Center Geomodel, Centre for X-ray Diffraction Studies (Saint-Petersburg State University).

Conflicts of Interest: The authors declare no conflict of interest.

\section{References}

1. Rudnick, R.L.; Gao, S. Composition of the continental crust. In Treatise on Geochemistry. The Crust; Elsevier: Amsterdam, The Netherlands, 2014; Volume 4, pp. 1-51.

2. Hartikainen, A. Soil geochemical studies in gold exploration at three targets in Haapoluoma, Seinäjoki, W-Finland. In Gold in Southern Finland: Results of GTK Studies 1998-2011; Special Paper; Grönholm, S., Kärkkäinen, N., Eds.; Geological Survey of Finland: Espoo, Finland, 2012; Volume 52, pp. 149-176.

3. Mackenzi, N.P.; Asigri, J.M.; Yidana, S.M.; Arhin, E.; Foli, G.; Kutu, J.M. Identifying pathfinder elements for gold in multi-element soil geochemical data from the Wa-Lawra Belt, Northwest Ghana: A multivariate statistical approach. Int. J. Geosci. 2012, 3, 62-70. [CrossRef]

4. Carlos, A.S. Geokhemicheskie poiskovye priznaki zolotorudnoi mineralizatsii vistochnoi chasti Baltiskogo schita. Ph.D. Thesis, St.-Petersburg Mining University, St.-Petersburg, Russia, 2002.

5. Reis, A.P.; Sousa, A.J.; Cardoso Fonseca, E. Soil geochemical prospecting for gold at Marrancos (Nothern Portigal). Geochem. Explor. 2001, 73, 1-10. [CrossRef]

6. McClenaghan, M.B.; Thorleifson, L.H.; DiLabio, R.N.W. Till geochemical and indicator mineral methods. Ore Geol. Rev. 2000, 16, 145-166. [CrossRef]

7. Antropova, L.N. Formy Nakhozhdenya Elementov v Oreolakh Rsseyanya Rydnykh Mestorozhdenii; NEDRA: Leningrad, Russia, 1975; p. 144. (In Russian)

8. Reith, F.; Cornelis, G. Effect of soil properties on gold- and platinum nanoparticle mobility. Chem. Geol. 2017, 466, 446-453. [CrossRef]

9. Reith, F.; Lenggke, M.F.; Falconer, D.; Craw, D.; Southam, G. The geomicrobiology of gold. ISME J. 2007, 1,567-584. [CrossRef] [PubMed]

10. Tosiani, T. Low temperature Au-humic acid interaction experiments: Implication for Au transport in surface conditions. Mineral. Mag. 1998, 62A, 1531-1532. [CrossRef]

11. Freyssient, P.; Itard, Y. Geochemical mass balance of gold under various tropical weathering condition: Application to explaration. Explor. Geochem. 1997, 42, 347-354.

12. Geological Survey of Finland Home Page. Available online: http://tupa.gtk.fi/karttasovellus/mdae/ raportti/296_Jousij\%C3\%A4rvi.pdf (accessed on 16 February 2018).

13. Novoselov, K.A.; Belogyb, E.V.; Ermolina, O.S. Predvaritelnyi Otchet po Rezultatam Revizii Skvazhin Litsenzionnoi Ploschadi Piilola; Miass, Russia, 2011; 26p, (Unpublished). (In Russian)

14. Kellaway, B. Mineral Exploration Network Home Page. Available online: http://kareliangold.com/wpcontent/uploads/2013/02/MENFin_2013_FINAL_20130221.pdf (accessed on 30 September 2018).

15. Kyleshevich, L.V.; Tytyk, V.M. Metamorfogenno-metasomaticheskie preobrazovanya i Au-S-As mineralizatsya mestorozhdenya Novye Peski (Iyzhnaya Karelia). Geol. I Miner. Resur. Karelii 2014, 17, 59-73. (In Russian) 
16. Dokuchaev, A.Y.; Nosova, A.A.; Tytyk, V.M. Novye Peski mesothermal gold deposit in the amphibolite-facies rocks Central Karelia: Its mineraligical features and possible analogues at the Baltic shield. In Gold of the Fennoscandian Shield, Proceedings of the International Conference; Institute of Geology, KarRC, RAS: Petrozavodsk, Russia, 2013; pp. 56-60. (In Russian)

17. Fedorets, N.G.; Bakhmet, O.N. Dinamika pochv i pochvennogo pokrova Karelo-Kolskogo regiona pod vlianiem prirodnykh faktorov. Trydi Naychnogo Karel'skogo Tsentra RAN 2016, 12, 39-51. (In Russian)

18. Mokma, D.L.; Ylli-Halla, M.; Lindqvist, K. Podzol formation in sandy soils of Finland. Geoderma 2004, 120, 259-272. [CrossRef]

19. Ylli-Halla, M.; Mokma, D.L. Problems Encountered When Classifying the Soils of Finland; Research Report No.7; Eouropean Soil Bureau: Ispra, Italy, 2002; pp. 183-189.

20. Garkusha, I.F. Pochvovedenie s Osnovami Geologii; Sel'hozizdat: Leningrad, Russia, 1963; p. 263. (In Russian)

21. Stifeeva, M.V. Mineralogo-Geokhimicheskie Osobennosti Gold-Ore Occurrences of Khaytovaaro-Vedlozero Area. Bachelor Thesis, Saint-Petersburg University, St.-Petersburg, Russia, 2014; p. 58.

22. Eilu, P. (Ed.) Mineral Deposits and Metallogeny of Fennoscandia; Spesial Paper 53; Geological Survey of Finland: Espoo, Finland; Tammerprint Oy: Tampere, Finland, 2012; p. 401, ISBN 978-952-217-175-7.

23. Lukonin, D. Archean and Proterozoic Gold Deposits. Master's Thesis, Luleå University of Technology, Luleå, Sweden, January 2008; p. 47.

24. Keon, N.E.; Swartz, C.H.; Brabander, D.J.; Harvey, C.; Hemond, H.F. Validation of an arsenic sequential extraction method for evaluating mobility in sediments. Environ. Sci. Technol. 2001, 35, 2778-2784. [CrossRef] [PubMed]

25. Kyznetsov, V.A.; Shimko, G.A. Metod Postadiinykh Vytyazhek Pri Geochimicheskich Issledovaniakh; Nayka i tekhnika: Minsk, Belarus, 1990; p. 64, ISBN 5-343-00598-5. (In Russian)

26. Kononova, M.M.; Belchikova, N.P. Yskorennye metody opredelenia sostava gumusa mineral'nykh pochv. Pedology 1961, 10, 75-85. (In Russian)

27. Novitsky, M.V.; Donskikh, I.N.; Chernov, D.V.; Nazarova, A.V.; Melnikov, S.P.; Baeva, N.N.; Lavrischev, A.V. Laborotorno-Prakticheskie Zanyatia po Pochvovedeniu. Uchebnoe Posobie; Prospekt Nauki: S.-Petersburg, Russia, 2009; p. 320, ISBN 978-5-90309O-31-0. (In Russian)

28. Roslyakov, N.A. Geokhimia zolota v zone gipergeneza; Nauka: Novosybirsk, Russia, 1981; p. 238. (In Russian)

29. Ran, Y.; Fu, J.; Rate, A.W.; Gilkes, R.J. Adsorption of Au(I, III) complexes on Fe, Mn oxides and humic acid. Chem. Geol. 2002, 185, 33-49. [CrossRef]

30. Gray, D.J.; Lintern, M.J.; Longman, G.D. Chemistry of Gold-Humic Interaction CSIRO Division of Exploration Geoscience Report 128R; Second impression (1998); CRC LEME: Wembley, Australia, 1990; p. 32, ISBN 0642282072.

31. Varshal, G.M.; Velykhanova, T.K.; Baranova, N.N. Vzaimodeistvie zolota s guminovymi veschestvami prirodnykh vod, pochv i porod (geochimicheskyi i analiticheski aspekt). Geokhimia 1990, 3, 316-327. (In Russian)

32. Baker, W.E. The role of humic acid in the transport of gold. Geochimica et Cosmochimica Acta 1978, 41, 645-664. [CrossRef]

(C) 2019 by the authors. Licensee MDPI, Basel, Switzerland. This article is an open access article distributed under the terms and conditions of the Creative Commons Attribution (CC BY) license (http://creativecommons.org/licenses/by/4.0/). 